\title{
Catchment management in semi-arid area of central South Africa: Strategy for improving water productivity
}

\author{
YE Woyessa ${ }^{1 *}$, M Hensley ${ }^{2}$ and LD van Rensburg ${ }^{2}$ \\ ${ }^{1}$ School of Civil Engineering and Built Environment, Central University of Technology, Free State Private Bag X20539, \\ Bloemfontein 9300, South Africa \\ ${ }^{2}$ Department of Soil, Crop and Climate Sciences, University of the Free State, PO Box 339, Bloemfontein 9300, South Africa
}

\begin{abstract}
In the semi-arid part of central South Africa, population growth and industrial development are the driving forces for an increased demand for water. This accentuates the need for wise decisions by catchment management agencies (CMAs), especially in water-scarce semi-arid areas. These decisions become more and more complex as the range of demands widens over the spectrum of water consumers, i.e. municipal, industrial, irrigation and rain-fed farming. A study was conducted in the Upper Modder River catchment, which is situated in the semi-arid area of central South Africa, where crop production in the catchment using conventional production technique is currently not suitable due to marginal and erratic rainfall. Moreover, the area is characterised by low precipitation use efficiency because of large runoff and evaporation losses on clay and duplex soils. A labour intensive in-field rainwater harvesting (IRWH) technique recently introduced into a part of the basin occupied by communal farmers has been shown to increase maize and sunflower yields by 30 to $50 \%$ compared to conventional tillage, making it a feasible option for the subsistence farmers in the catchment. The area of land suitable for the IRWH located in the communal land is estimated to be 23000 ha. Two catchment management options presented in this paper are:

- Option1: allowing the IRWH suitable land in the communal farming area to remain under grassland and utilising the runoff downstream for irrigating maize

- Option 2: utilising the IRWH suitable land for maize production in the basin, using the IRWH technique

Results showed that the expected maize production from Option 2 was higher than from Option 1. A financial analysis also showed that gross margin of option, expressed as $\mathrm{R} / \mathrm{m}^{3}$ of rainwater utilised, was estimated to be between 0.0234 to 0.0254 under Option 1 and 0.0354 for Option 2. This clearly shows that use of rainwater where it falls has high socio-economic benefits for the communal farmers who are currently struggling to achieve sustainable livelihoods.
\end{abstract}

Keywords: catchment management, rainwater harvesting, water productivity, small-scale farmers

\section{Introduction}

In a new paradigm shift related to integrated water resources management in the context of a river basin, attention is being drawn to the upstream influences on the various water use entities, as well as the downstream impacts arising from them. Along the path of water flowing in a river basin are many water-related human interventions, such as water storage, diversion, regulation, pollution, purification, etc. and associated acts to modify the natural systems. All of these have one common effect, and that is that they impact on those who live downstream (Sunaryo, 2002).

In rain-fed agriculture water productivity will have to increase dramatically over the next generations if food production is to keep pace with human population growth (Rockström et al., 2002). In Sub-Saharan Africa, over $60 \%$ of the population depends on rain based rural economics, generating about 30 to $40 \%$ of the regions GDP (World Bank, 1997). However, in many parts of the water scarce countries, yields from rainfed agriculture are low, oscillating around $1 \mathrm{t} / \mathrm{ha}$ (Rockström, 2001). Many researchers, however, suggest that the low productivity in rain-fed agriculture is more due to sub-optimal

This paper was originally presented at the 2006 Water Institute of South Africa (WISA) Biennial Conference, Durban, South Africa, 21-25 May 2006

* To whom all correspondence should be addressed.

巡+2751 507-3647; fax:+2751 507-3254; e-mail: ywoyessa@cut.ac.za performance related to management aspects than to low physical potential. For instance, Bennie et al. (1994) reported that in arid and semi-arid areas between 60 and $85 \%$ of the rainfall evaporates from the soil surface without making any contribution to production.

In the semi-arid part of central South Africa, population growth and industrial development are the driving forces for an increased demand for water. This accentuates the need for wise decisions by catchment management agencies (CMAs), especially in water scarce semi-arid areas. These decisions become more and more complex as the range of demands widens over the spectrum of water consumers, i.e. municipal, industrial, irrigation and rain-fed farming. Due to its location, which is close to the relatively densely populated and industrialised greater Mangaung Municipal area that includes Bloemfontein, Botshabelo and Thaba Nchu, the Upper Modder River (UMR) catchment is of strategic importance, with the widest possible range of competing stakeholders. It is therefore important that the CMA's decision for this and other similar catchment be based on reliable information. The objective of this paper is to provide essential new information relevant to the rain-fed crop production by subsistence farmers in the UMR catchment.

\section{The Upper Modder River catchment and subsistence agriculture}

A detailed description of the UMR catchment is given by Woyessa et al. (2006). The area is 295766 ha, mean annual pre- 


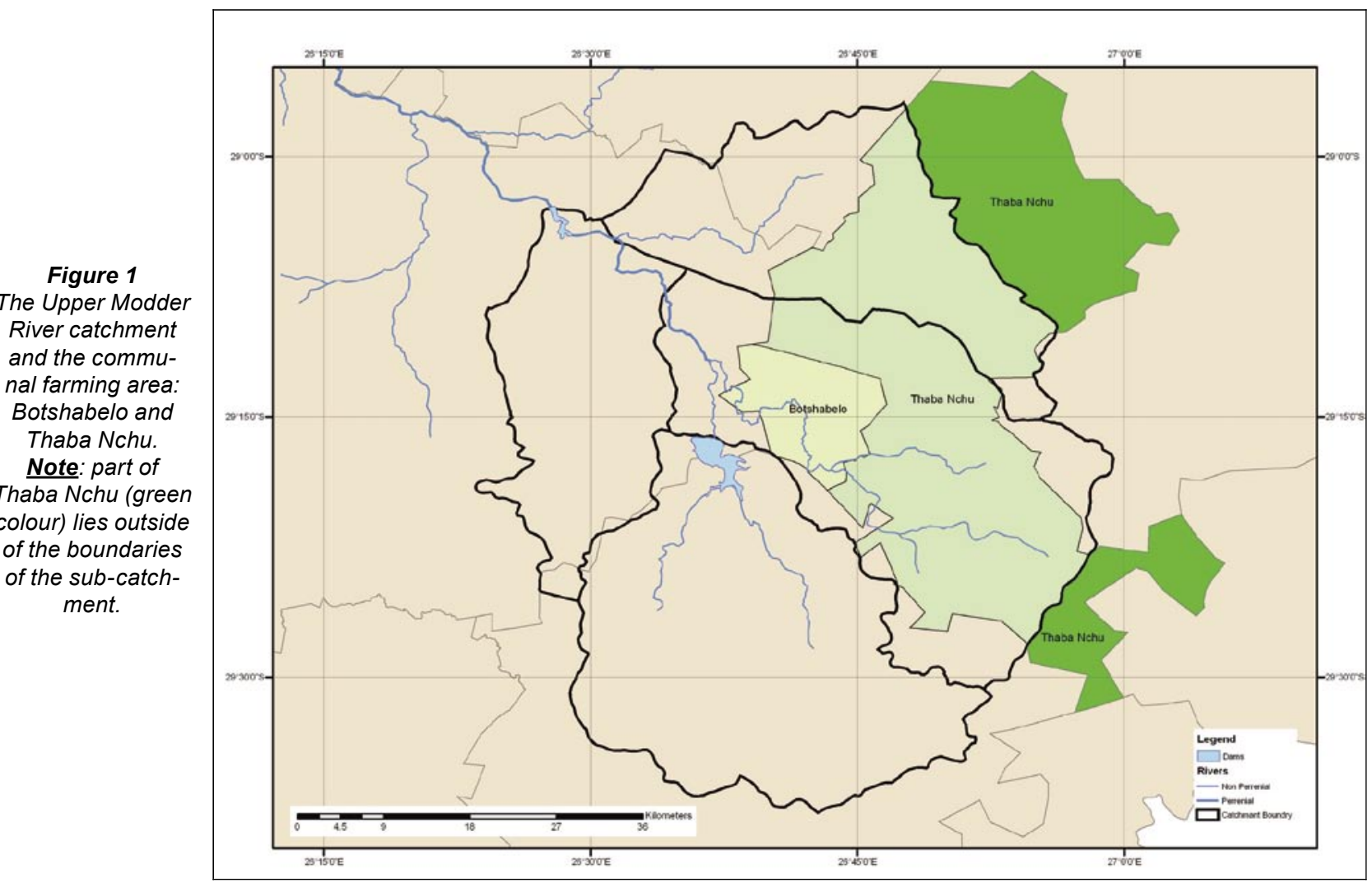

cipitation of $537 \mathrm{~mm}$ and average runoff coefficient of $5.95 \%$. The mean annual runoff from the total area is estimated at 94.42 $\mathrm{x} 10^{6} \mathrm{~m}^{3}$. Included in the catchment is around 70000 ha of communal land (Fig. 1) occupied by subsistence farmers with a low standard of living.

The area is characterised as marginal for crop production due to low and erratic rainfall combined with clay and duplex soils, and high water losses by runoff and evaporation. Orthophoto maps of the area at a scale of 1:10 000 published in 2002 (Chief Directorate: Surveys and Mapping, 2002) show a negligibly small area being cultivated currently, but a large area of old cultivated land. The maps also show considerable soil erosion that is a result of conventional tillage. However, mixed messages are obtained if one inquires as to why cultivation was stopped in this part of the central region. There is, however, no doubt that low yields, progressively declining because of failure to fertilise adequately was probably an important factor. The Agricultural Research Council's (ARC) Institute for Soil, Climate and Water (ISCW) has done effective agricultural research and extension work over the past nine years at Glen in an effort to improve the livelihoods of the subsistence farmers through increased crop yield.

The crop production in this area is marginal using conventional tillage, i.e. mouldboard ploughing followed by disking or harrowing to prepare a fine seedbed. As water conservation alternative an Infield Rainwater Harvesting technique (IRWH) was developed to improve yields (Hensley et al., 2000; Botha et al., 2003). It is described in Fig. 2. By using a crop model together with long-term rainfall data it was possible to predict long-term yields of maize and sunflower using conventional tillage (CON) and IRWH, as shown in Fig. 3 (Botha et al., 2003). It has, therefore, been clearly shown that the livelihoods of the subsistence farmers would be improved if they employed IRWH for maize and sunflower production.
The main aspect of the IRWH technique is that it reduces runoff to zero. If this technique is widely adopted, a possible change in catchment hydrology needs to be considered and evaluated by CMAs in relation to the many other demands for water in this important catchment. Woyessa et al. (2006a and $b$ ) provide valuable information in this regard highlighting the comparison in economic terms of the two strategies, namely:

- No IRWH in the catchment and using the runoff for irrigation below the storage dams

- All suitable land in the catchment under IRWH.

They concluded that in purely economic terms the latter was found to be the best strategy. The aim of this paper is to present the results of a study on the different catchment management options for efficient use of rainfall.

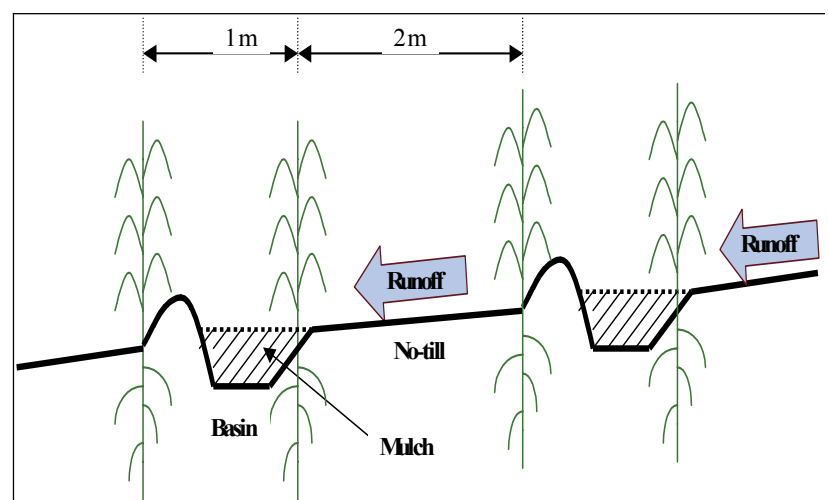

Figure 2

Diagrammatic representation of the Infield Rainwater Harvesting (IRWH) technique (adapted from Hensley et al., 2000) 


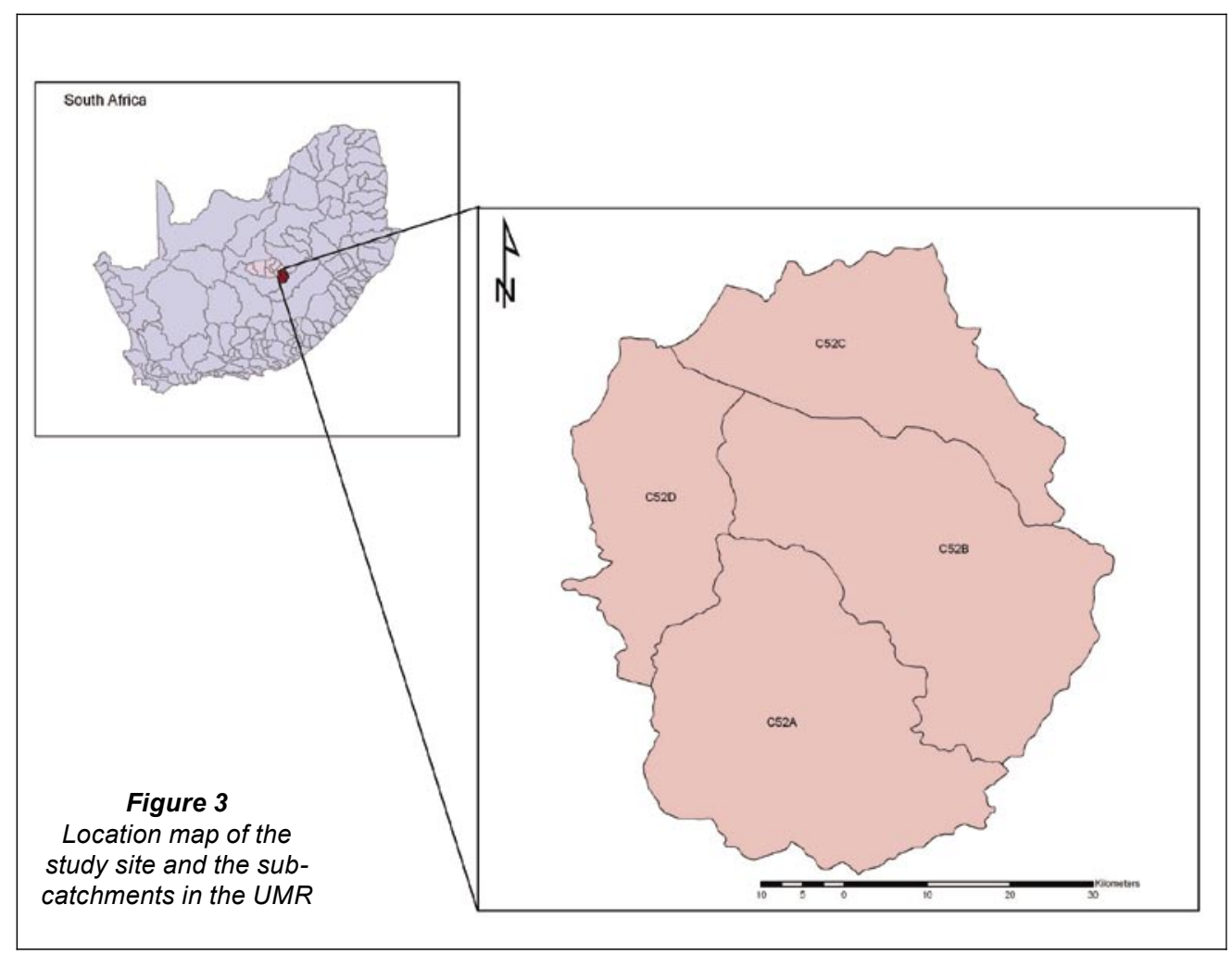

\section{Methodology}

The Modder River basin is a large basin with a total area of $1.73 \times 10^{6}$ ha. It is divided into three sub-basins, namely the Upper Modder, the Middle Modder and the Lower Modder. It is located within the semi-arid Upper Orange Water Management Area to the east and north of the city of Bloemfontein, central South Africa. A detailed description of the UMR catchment is given in Woyessa et al. (2006a and b).

\section{Estimating the area of communal IRWH land in the catchment}

Different land types have been identified in the catchment. Land Type Dc17 (Land Type Survey Staff, 2002) occupies 76\% of the UMR catchment. Eloff (1984) estimated that $10 \%$ of Dc17 is arable. Assuming that this fraction is fairly uniformly distributed over the whole area of the land type, and that "arable" is equivalent to "suitable for IRWH", this percentage can be used as a first approximation of IRWH land in the communal area component of the catchment. Tekle (2004) investigated the soilscape procedure in an attempt to refine the evaluation of Dc17 for IRWH and also described the procedure used. It involves subdividing a land type into carefully selected smaller areas, termed soilscapes, with similar topography and geology. Because of the very important role which these two factors play in soil genesis in this semi-arid area, soil distribution in a soilscape can be assumed to be more homogenous than in its parent land type. Due to this, estimates of IRWH land based on soilscapes should be better than those based on the parent land type.

\section{Estimating the economic benefit of IRWH to the subsistence farmers}

The enterprise budget for maize production complied by Kundhlande et al. (2004) was used in the analysis of the economic benefit of IRWH to the subsistence farmers. This includes land preparation, maintenance (repair of basins) and harvest and post-harvest labour.

\section{Estimating the decrease in runoff from the UMR catchment due to the IRWH}

The amount of runoff that could be retained by IRWH was estimated from the total estimated runoff and the amount of land suitable for this technique. The total area of suitable land for IRWH was estimated to be $22 \%$ of the total area of the land in the catchment. The mean annual total runoff and the amount of runoff retained by the IRWH were then estimated from the mean total rainfall of $537 \mathrm{~mm}$ and a runoff coefficient of $5.95 \%$.

\section{Results and discussion}

Tekle (2004) presents a table with the total area of each of 66 components of Dc17 and a map showing the boundaries of each soilscape. The original boundaries were drawn on maps with a scale of 1:50 000. By transforming these boundaries to a map with a scale of 1:250 000 and superimposing it on a map of similar scale showing the boundaries of the communal land, it is possible to identify the whole soilscape, or portions of soilscape, that are located on the communal land. Using these results together with the estimate by Tekle (2004), it was possible to obtain what is considered a reasonable final estimate of IRWH land in the communal area of the UMR catchment. The result is 23000 ha or $22 \%$ of the total area. Recent soil surveys in the area indicate that this estimate may be somewhat too high. Using the procedure of Eloff (1984), i.e. 10\% arable land, would give 10000 ha It is necessary to note here that there would be a danger of disturbing the ecological balance in the catchment if more than $30 \%$ of the area was used for IRWH (Van Collar, 2004).

Based on detailed economic analyses Kundhlande et al. (2004) concluded that by adopting the simplest form of infield rainwater harvesting - without the use of mulches in the basins and runoff area, farmers can increase their income by R800/ha·a 
Figure 4

Mean annual runoff from

the total area of the catchment and the amount of

runoff that can be retained by the IRWH in all the suitable land in the Upper Modder River catchment. Precipitation; MAR-Total = Total Mean Annual RunAnnual Runoff retained by the IRWH; MAR-Non IRWH = Mean Annual Runoff available from non-IRWH lands.
Note: $M A P=$ Mean Annual off; $M A R-I R W H=$ Mean

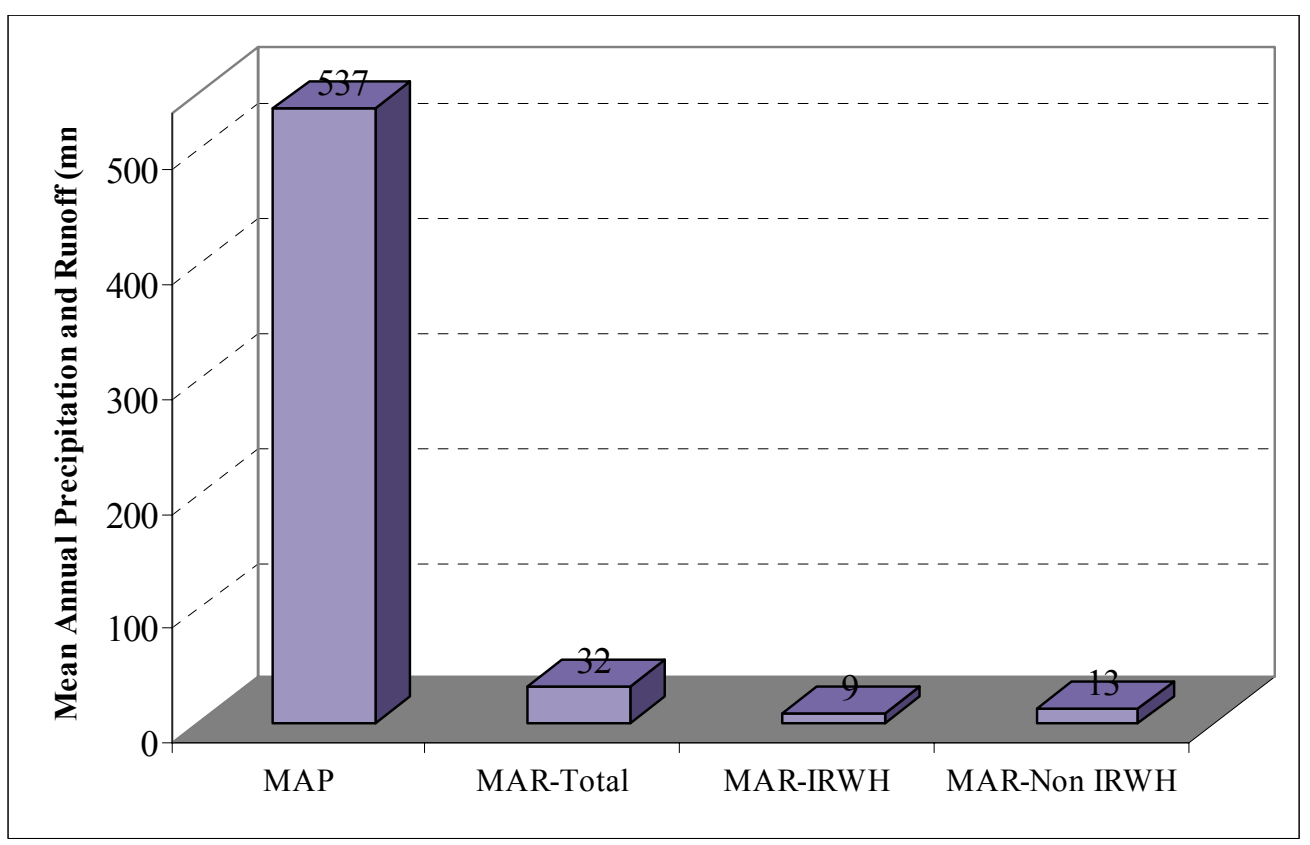

in the case of maize production. The values presented for gross margin above the total allocatable costs vary depending on the type of IRWH employed for maize production, but are generally around R1 200/ha a. It needs to be kept in mind that, apart from food grown in home gardens, crop production in the communal land is currently almost negligible. Farmers have an allocation of about 1 to 5 ha of cropland. It is therefore clear that employing IRWH efficiently on that sort of area would have a significant beneficial effect on their livelihood.

\section{Possible impact of the rainwater harvesting technique on runoff}

The mean annual runoff and the amount of runoff expected to be retained in the IRWH suitable are within the communal lands in the catchment are presented in Fig. 4. If runoff from this portion of the catchment is captured for on-site use for crop production using the IRWH technique, it is estimated that it will retain a mean annual runoff of $9 \mathrm{~mm}$, decreasing the mean annual runoff from $32 \mathrm{~mm}$ to $13 \mathrm{~mm}$ (Fig. 4). It should be noted that, in this part of the country, mean annual evaporation (Class A pan) is $2198 \mathrm{~mm}$ (Botha et al., 2003) which can cause a tremendous amount of water loss from dams, rivers and other storage reservoirs. For instance it is estimated that $25.5 \times 10^{6} \mathrm{~m}^{3}$ of water can be lost annually through evaporation from Rustfontein Dam, located in the catchment, with storage surface area of $1158.5 \mathrm{ha}$. This is one of the losses of water that can be avoided by the onsite use of rainwater at upstream level for food production.

However, the assumption of the scenario of all the suitable land for IRWH being put under cultivation using the IRWH technique should be seen in relation to the following factors. Firstly, the current form of the IRWH technique has been designed for implementation using hand labour, and therefore only suitable for the relatively small areas expected to be developed initially by communal farmers living in the catchment area. The estimated area of suitable land for the IRWH technique inhabited by communal farmers is 23000 ha. At present, the IRWH technique is employed almost exclusively by large numbers of the communal farmers in their backyard gardens. The rate of expansion into the 23000 ha of communal cropland is expected to be determined by the extent and rate at which certain socioeconomic constraints can be overcome. Secondly, research is currently being planned to mechanise the IRWH technique and make it suitable for commercial production. If this proves to be successful, expansion would probably be accelerated.

However, it is useful to see the implications for catchment management decisions in terms of the possible impact of the different scenarios of rain water use, namely on-site vs. off-site, in relation to water productivity and some economic factors. These are discussed in the following sections.

\section{Implications for catchment management decisions}

There is a growing need for wise catchment management decisions in the whole of South Africa in general and the Modder River basin in particular, because water is such a limiting factor. This need has been recognised in the new National Water Act by the creation of catchment management agencies (CMAs) (DWAF, 2004).

The two options regarding the catchment management decisions that need to be addressed are:

- Allowing the IRWH suitable areas to remain under grassland and utilising the runoff which occurs from it to flow via storage dams and be used downstream for irrigation OR

- Utilising all the rainfall on the IRWH suitable land for growing maize (or sunflower) using the IRWH technique on site.

These two catchment management options are illustrated using schematic representation in Fig. 5. The detailed calculations and discussion on these two options have been reported by Woyessa et al. (2006a and b). Here, these two options are summarised under the following two sections.

\section{Crop production and water productivity in the catchment}

In sub-Saharan Africa, rain-fed agriculture is practiced on approximately $95 \%$ of agricultural land, with only $5 \%$ under irrigation (Rockström et al., 2002). This shows that rain-fed 


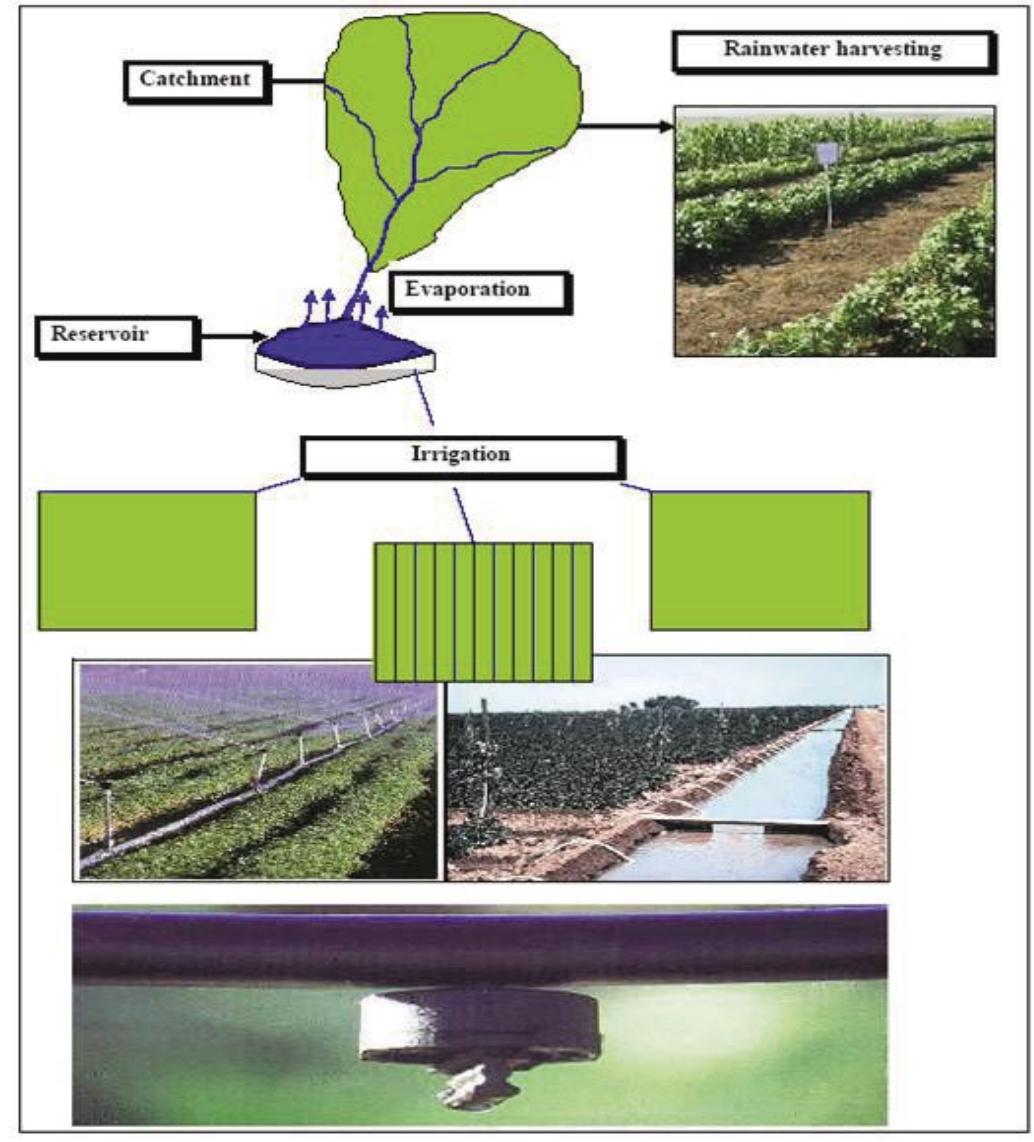

Figure 5

Diagrammatic representation of the two catchment management strategies.

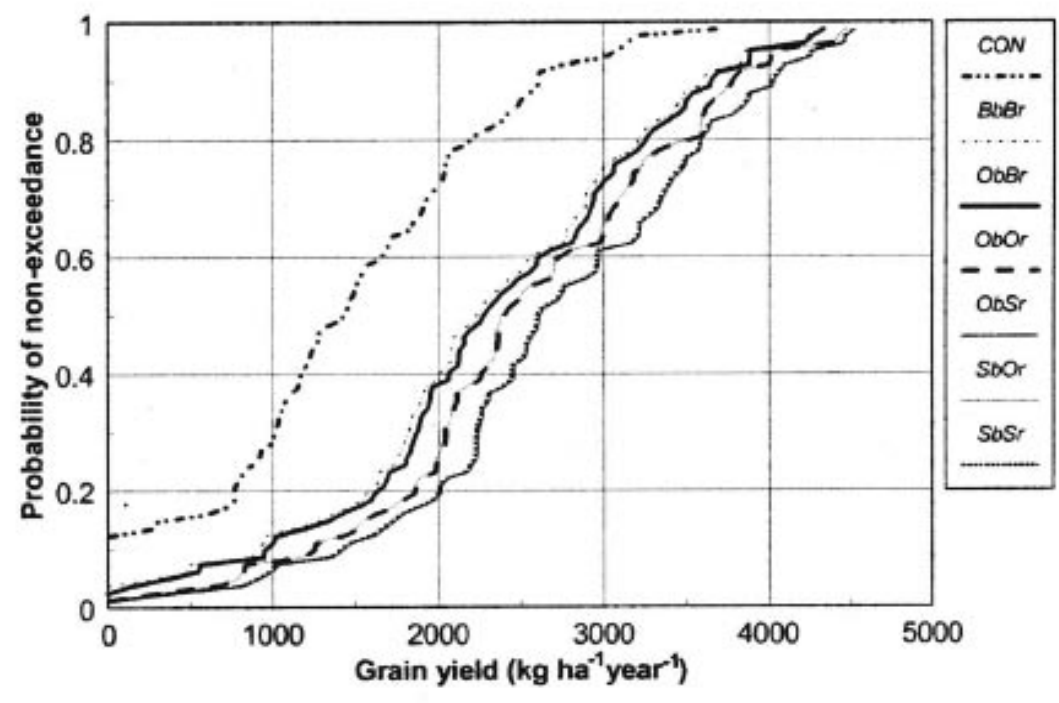

Figure 6

Maize grain yield and the probability of non-exceedance for different production techniques (from Botha et al., 2003).

agriculture will remain the dominant source of food production for the foreseeable future in the region. Thus, increasing the productivity of water in agriculture will play a vital role in easing competition for scarce resources, prevention of environmental degradation and provision of food security (Molden et al., 2003).
Using the procedure described by Woyessa et al. (2006a and b), the mean annual runoff retained in the 23000 ha of IRWH land is estimated to be $7.34 \times 10^{6} \mathrm{~m}^{3}$. It is reasonable to assume long term average maize yields of 1.7 and $0.8 \mathrm{t} /$ ha with the IRWH and CON production techniques respectively. These results can be read from the graph in Fig. 6, using $80 \%$ probability of achievement (or $20 \%$ probability of non-exceedance). It can therefore be calculated that the increase in yield of $0.9 \mathrm{t} / \mathrm{ha}$ is due to the water which did not run off the IRWH lands, i.e. $7.34 \times 10^{6} \mathrm{~m}^{3}$ from an area of 23000 ha. The water productivity of this runoff water can therefore be estimated as follows:

$$
\begin{aligned}
& \frac{0.9 \times 10^{3} \mathrm{~kg} \mathrm{ha}^{-1}}{7.34 \times 10^{6} \mathrm{~m}^{3} / 23 \times 10^{7} \mathrm{~m}^{2}} \\
& =28.2 \mathrm{~kg} \mathrm{ha}^{-1} \mathrm{~mm}^{-1}
\end{aligned}
$$

The above value shows a high water productivity indicating a large benefit that could result from using the IRWH in terms of meeting the food security as well as preventing erosion and sedimentation of downstream rivers.

It has been reported that crop production in the study area under dry-land and conventional tillage is very marginal because of relatively low and erratic rainfall and predominantly duplex and clay soils on which the precipitation use efficiency is low due to large runoff and evaporation losses from the soil surface (Hensley et al., 2000). Because of this, maize production using conventional tillage in the UMMRB is currently almost negligible. The two catchment management strategies given in Fig. 7 are, firstly, veld grass in the catchment and using the runoff for centre-pivot irrigation downstream; and secondly the application of the IRWH technique in the catchment.

Included in the calculations are the losses from the original runoff water which occur due to evaporation from the storage dams, and transmission downstream to the hypothetical site of irrigation. Reliable values for these parameters are currently not available. As a preliminary solution to this difficulty, two scenarios are presented in Fig. 7, using two fairly extreme values for storage and conveyance losses, i.e. $35 \%$ (Scenario A) and $60 \%$ (Scenario B). For irrigation a centre-pivot system with $75 \%$ efficiency was assumed. The total water requirement of a target yield of $10 \mathrm{t} /$ ha maize was estimated to be $735 \mathrm{~mm}$ (Bennie et al., 1988).

The results presented in Fig. 7 show the expected total production under the two production strategies. The monetary benefit derived from these different strategies will be dealt with in the financial analysis (Fig. 4). The comparison of total maize production under the two production strategies shows that using rainfall where it falls in the catchment with the IRWH technique 
results in the production of six times more maize than the downstream irrigation strategy. This information makes it quite clear that the on-site use of rainwater as described constitutes the best catchment management decision. It should also be noted that investment in the development of irrigation systems for a viable farming business is far from being accessible to small scale farmers who are struggling to meet their daily food requirement. The IRWH technique therefore offers an attractive option at this moment towards meeting household food security in the communal farming area. This, however, will require a concerted effort on the part of the Department of Agriculture and other stakeholders to promote the technique and to develop the skills of the small-scale farmers to make the system sustainable.

\section{Financial assessment of the catchment management strategies}

A preliminary financial assessment of the two strategies, presented in Fig. 8, shows that the combined irrigation plus veld grazing strategy is shown to yield a combined gross margin of 0.0254 and $0.0234 \mathrm{R} / \mathrm{m}^{3}$ of rain water, for scenarios of $\mathrm{A}$ and $\mathrm{B}$ respectively. The detailed calculation of the gross margin for the two catchment management strategies is reported in Woyessa et al. (2006a and b). The comparable figure for the use of the IRWH technique to produce maize is $0.0354 \mathrm{R} / \mathrm{m}^{3}$. In monetary terms, the estimated IRWH advantage compared to irrigation plus veld grass amounts to R4.3 m. and R5.2 m./a for scenarios $\mathrm{A}$ and $\mathrm{B}$ respectively.

The results in Fig. 8 provide additional economic support for the conclusions. It is clear that it would be a wise catchment management decision to allow maize production using the IRWH technique to be developed in the UMR catchment. It is of value to include here relevant information presented by Kundhlande et al. (2004), i.e. that among the communal farmers a family of five needs about $1 \mathrm{t}$ maize/a to supply their staple food. Therefore, the estimated maize production on the approximately 23000 ha of the IRWH suitable land in the communal farming area within the UMR catchment would be sufficient to supply the staple food for about 39100 families or 195500 people.

\section{Conclusion}

The ultimate goal of water resources policy in a catchment management is to increase the beneficial utilisation of the rainwater falling in the catchment through reduction of non-beneficial losses and water pollution. Infield rainwater harvesting together with appropriate farming practices can contribute towards achieving this goal. The IRWH technique introduced to the subsistence communal farmers in the UMR catchment is one such practice designed to increase crop yields under dry-land production compared to conventional tillage, and hence increase water productivity.

The result of this study shows clearly that from all points of view, i.e. water productivity, social considerations and economics, it would be a wise decision to allow the IRWH technique to be expanded in the UMR catchment. However, this does not imply that downstream irrigation farming should be scaled-down in favour of the application of the IRWH technique at the upstream level. Nevertheless, the challenges faced by these farmers in the application of the IRWH technique are such that it could affect the expansion thereof, and should be addressed by the concerned governmental departments and non governmental organisations operating in the area. However, a regulating factor in the future will be the growing need for more

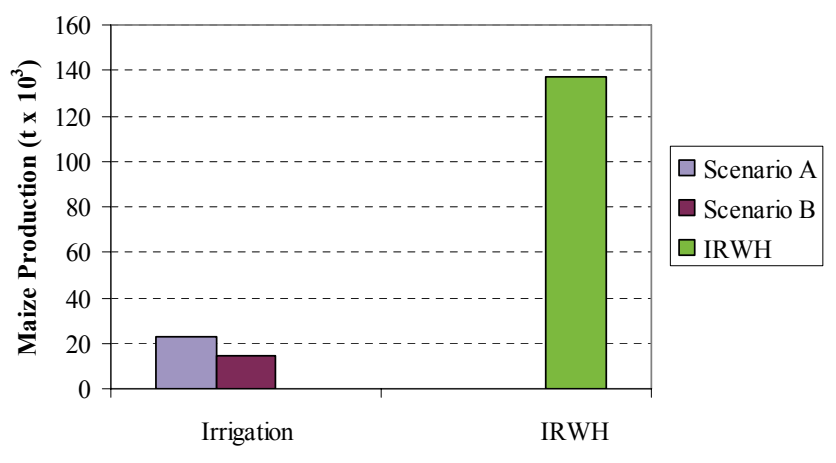

Catchment Management Strategy

Figure 7

Comparison of use of rainwater under upstream (IRWH) and downstream (Irrigation) for agricultural production (in case of irrigation, storage plus conveyance losses are assumed to be $35 \%$ and $60 \%$ for scenario $A$ and $B$ respectively)

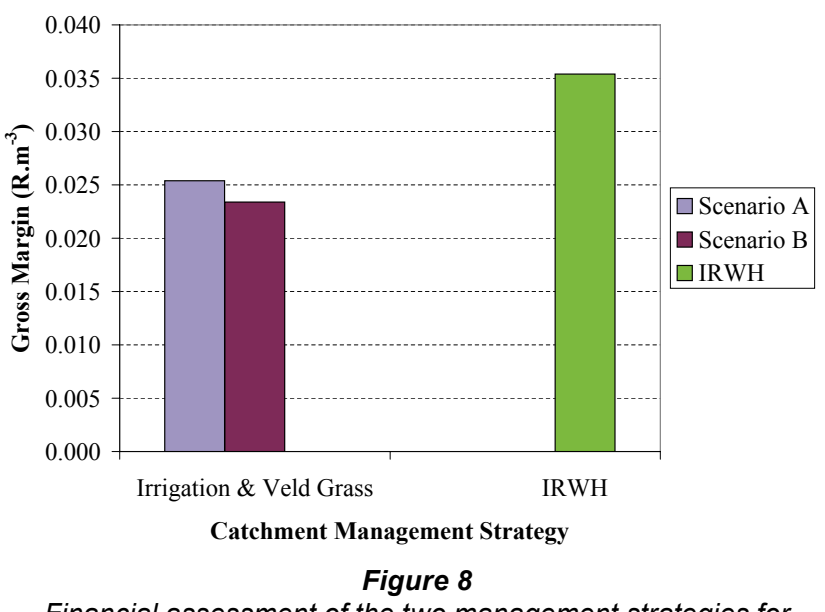

Financial assessment of the two management strategies for maize production (Scenarios $A$ and $B$ are as described in Fig. 7)

water for municipal and industrial purposes in the ever growing Bloemfontein, Botshabelo and ThabaNchu areas. Thus, it should be emphasised that water loss reduction and management are considered to be part of a basin-wide integrated water resource management, which gives an essential role to institutions and policies in ensuring that upstream interventions are not made at the expense of downstream water users. These principles apply at all scales, from field to basin levels, but the associated options and practices require different approaches at different spatial scales. Therefore, there is a need to identify the types of policies and incentives that will work best in promoting adoption of new production techniques and cultural practices which increase water productivity at all levels.

\section{References}

BENNIE ATP, COETZEE MJ, VAN ANTWERPEN R, VAN RENSBURG LD and BURGER R du T (1988) A water balance model for irrigation based on the soil water supply rate and crop water requirements (Afrikaans). WRC Report No. 144/1/88. Water Research Commission, Pretoria, South Africa.

BENNIE ATP, HOFMAN JE, COETZEE MJ and VERY HS (1994) Storage and utilization of rainwater in soils for stabilizing crop production in semi-arid areas. (Afrikaans) WRC Report No. 227/1/94. Water Research Commission, Pretoria, South Africa.

BOTHA JJ, VAN RENSBURG LD, ANDERSON JJ, HENSLEY M, MACHELLI MS, VAN STADEN PP, KUNDHLANDE G, GROENEWALD DG and BAIPHETHI MN (2003) Water conser- 
vation techniques on small plots in semi-arid areas to enhance rainfall use efficiency, food security, and sustainable crop production. WRC Report No 1176/1/03. Water Research Commission, Pretoria, South Africa.

CHIEF DIRECTORATE: SURVEYS AND MAPPING (2002) Department of Land Affairs. South African Government. Pretoria.

DEPT OF WATER AFFAIRS AND FORESTRY (2004) National Water Resources Strategy ( $1^{\text {st }}$ edn.) Department of Water Affairs and Forestry, Pretoria.

ELOFF JF (1984) Die Grondhulpbronne van die Vrystaatstreek. Unpublished Ph.D. Thesis, University of Stellenbosch, Stellenbosch.

HENSLEY M, BOTHA JJ, ANDERSON JJ, VAN STADEN PP and DU TOIT A (2000) Optimizing rainfall use efficiency for developing farmers with limited access to irrigation water. WRC Report No. 878/1/00. Water Research Commission, Pretoria, South Africa.

KHUNDHLANDE G, GROENEWALD DC, BAIPHETHI MN, VILJOEN MF, BOTHA JJ, VAN RENSBURG LD and ANDERSON JJ (2004) Socio-Economic Study on Water Conservation Techniques in Semi-Arid Areas. WRC Report No. 1267/1/04. Water Research Commission, Pretoria, South Africa.

LAND TYPE SURVEY STAFF (2002) Land Type Soil and Terrain Inventories from Northern Cape, Free State, North West, Gauteng, Kwazulu-Natal and Eastern Cape Provinces. Land Type Survey Database. ARC-ISCW, Pretoria.

MOLDEN D, MURRAY-RUST H, SAKTHIVADIVEL R and MAKIN I (2003) A water productivity framework for understanding and action. In: JW Kijne, R Barker and D Molden (eds.) Water Productivity in Agriculture: Limits and Opportunities for Improvement. CAB International.

ROCKSTRÖM J (2001) Green water security for the food makers of tomorrow: windows of opportunity in drought prone savannahs. Water Sci. Technol. 43 71-78.

ROCKSTRÖM J BARRON J AND FOX P (2002) Rainwater management for increased productivity among small-holder farmers in drought-prone environments. Phys. Chem. Earth 27 949-959.

SUNARYO TM (2002) Integrated water resource management in a river-basin context: The Brantas River basin, Indonesia. In: B Bruns, DJ Bandaragoda and M Samad (eds.) Integrated Water Resources Management in a River Basin Context: Institutional Strategies for Improving the Productivity of Agricultural Water Management. Proceedings of the Regional Workshop. Malang, Indonesia, January 15-19, 2001. Colombo, Sri Lanka: International Water Management Institute. 277-305.

TEKLE SA, HENSLEY M and LE ROUX PAL (2004) Soilscape survey for planning in-field rainwater harvesting in Thaba Nchu, Central Free State. Proc. Symp. S. Afr. Nat. Comm. Irrig. Drain. 17-19 November 2004, Fish River Sun, South Africa. CD ROM.

TEKLE SA (2004) A Soilscape Survey to Evaluate Land for In-field Rainwater Harvesting in the Free State Province, South Africa. M.Sc. Thesis, University of the Free State, Bloemfontein.

VAN COLLAR (2004) Personal communication. National Department of Agriculture. Pretoria.

WORLD BANK (1997) World Development Report 1997. World Bank, Washington DC. 354.

WOYESSA YE, PRETORIUS E, HENSLEY M, VAN RENSBURG LD and VAN HEERDEN PS (2006a) Up-scaling of rain-water harvesting for crop production in the communal lands of the Modder River basin in South Africa: Comparing upstream and downstream scenarios. Water SA 32 (2) 223-228.

WOYESSA YE, PRETORIUS E, VAN HEERDEN PS, HENSLEY M, and VAN REANSBURG LD (2006b) Impact of Land Use on River Basin Water Balance: A Case Study of the Modder River Basin, South Africa. Comprehensive Assessment Research Report 12. Colombo, Sri Lanka: Comprehensive Assessment Secretariat. Also available online at: http://www.iwmi.cgiar.org/assessment/ files_new/publications/CA\%20Research\%20Reports/CARR12low.pdf 